\title{
Integrative Systemic Therapy in Foreign Language Learning: A Practical Framework for Managing Foreign Language Listening Anxiety among Iranian EFL Learners
}

\section{Farid Khezr Minaei ${ }^{1 *}$ \& Mahvash Gholami ${ }^{1}$}

* Correspondence:

farid.minae@gmail.com

1. Department of Foreign Languages,

Faculty of Literature and Humanities,

Kharazmi University, Tehran, Iran

Received: 16 May 2021

Revision: 24 July 2021

Accepted: 8 September 2021

Published online: 20 December 2021

\begin{abstract}
This study aimed at proposing a framework based on Integrative Systemic Therapy (IST) for addressing foreign language listening anxiety (FLLA) among Iranian learners of English as a Foreign Language (EFL). The effectiveness of the framework in reducing the levels of FLLA among language learners was investigated when implemented by a therapist as well as by learners independently. To this end, 30 intermediate EFL learners with high level of listening anxiety were selected as participants through convenience sampling. They were then randomly assigned into control group $(n=10)$, therapist group $(n=10)$, and self-therapy group $(n=10)$. The therapist group met with an experienced therapist once a week for a month and selftherapy group was just instructed on how to use the framework independently during the same period. The control group received no treatment. The scale developed by Kim (2000) for measuring FLLA and an IELTS listening test were used to explore the effectiveness of the framework. The results of the study revealed that the proposed framework was effective in reducing the levels of FLLA both when implemented by the therapist and by EFL learners independently. The findings reflected the importance of personalization when selecting foreign language anxiety-reducing strategies to enhance the effectiveness of the foreign language anxiety management.
\end{abstract}

Keywords: foreign language anxiety, foreign language listening anxiety (FLLA), integrative systemic therapy (IST), foreign language listening anxiety scale, EFL learners 


\section{Introduction}

Affective variables have received much attention from researchers and scholars in the field of Second Language Learning (Ehrman, 2002; Gardner, 1985; Leaver \& Atwell, 2002; Walqui, 2000). Proposing "The Affective Filter Hypothesis", Krashen (1982) has emphasized on affective variables as important factors in language learning process. He claims that learners with high motivation and low anxiety are expected to be more successful in second language learning.

One of the important variables that has received considerable attention in studies on individual differences is foreign language anxiety, a variable that emerged in studies from the 1970s (Kleinmann, 1977; Scovel, 1978). Horwitz, Horwitz, and Cope (1986) define foreign language anxiety as "a distinct complex of self-perceptions, beliefs, feelings, and behaviors related to classroom language learning arising from the uniqueness of the language learning process" (p.128). Numerous studies have been conducted on speaking, listening, reading, and writing anxieties (Argaman \& Abu-Rabia, 2002; Cheng, 2002; Saito, Horwitz, \& Garza, 1999; Woodrow, 2006; Zhai, 2015).

Although speaking in a foreign language is often reported by learners to be most anxiety provoking (Horwitz, 2001; Young, 1991), this anxiety could be related to a specific type of language skill such as listening or reading (MacIntyre \& Gardner, 1994). Listening anxiety is considered as one of the most important skill-specific anxieties. Since listening has a pivotal role in acquiring other language skills, the role of anxiety in listening apprehension is receiving increasing attention from educational practitioners and researchers alike (Young, 1991). Listening skill can determine to a great extent the success in language acquisition. Vandergrift (1999) recognizes listening comprehension as a highly integrative skill that facilitates the emergence of other language skills. Meanwhile, since speaking is based on the understanding of what is heard, therefore, effective communication is dependent on having good listening skill.

A review of the literature on FLLA unveils that although various anxiety-relieving strategies and interventions have been proposed, these strategies were used irrespective of considering particular characteristics of EFL learners and their problems. That is to say, previous studies used a similar set of anxiety-reducing strategies applicable to all situations and for all types of language learners. Hence, the role of contextualization of anxiety and anxiety-reducing strategies has been neglected so far. Therefore, the present study aimed at proposing a framework based on integrative systemic therapy (IST) for reducing or ideally eliminating foreign language anxiety in a more contextualized way.

\subsection{Statement of the Problem}

There have been many debates throughout the literature on why some language learners perform better in language learning than others. In fact, many internal and external factors are involved. Researchers had to accept the fact that personality traits such as self-esteem, inhibition, anxiety, risk-taking, and extraversion may well shape the ultimate success in mastering a foreign language (Dörney, 2005). Of these factors, foreign language anxiety received many attentions from researchers and scholars in the field of Second Language Acquisition.

Considering the importance of Foreign Language Anxiety (FLA) in the success of foreign language learning, a substantial body of research has been directed toward examining its causes and effects on language achievement (Gonen, 2009; Horwitz et al., 1986; Kim, 2000). Other studies attempted to develop and adopt strategies to alleviate foreign language anxiety of EFL students (Hashemi \& Abbasi, 2013; Ismail, 2016; Mejías, Applebaum, Applebaum, $\&$ Trotter, 1991). However, the proposed strategies and psychological interventions have been selected and used without any consideration of specific characteristics of EFL learners. In other words, there was no procedure to determine under which condition which strategy or intervention is useful for a particular language learner. Hence, the role of contextualization of anxiety and anxiety reducing strategies has been neglected in the previous studies.

All behaviors should be examined and understood in context. Foreign language anxiety is of no exception. The complex nature of FLA renders the field of second language learning in need of an organized system of care that is specific to context and condition of a particular language learner. Unfortunately despite the detrimental effects of anxiety on language learning process, there hasn't been any attempt to propose a systematic model for FLA management. Therefore, the present paper aims at proposing a framework adopted from IST for reducing or ideally eliminating foreign language anxiety in a more contextualized way.

This model through IST's essence diagram takes specific characteristics of each EFL learner and works collaboratively with them to define a learner specific problem, construct a problem sequence, identify a solution sequence and implement it. IST emphasizes creating a structure for case formulation and intervention that suggests under which 
situations which intervention strategies are likely to be the most valuable (Pinsof et al., 2018). In addition, IST does not focus on the causes of a problem, instead, it attempts to replace patterns of behavior which triggers the problem with a new one. The hope of this study is to propose a framework for understanding the nature of foreign language (FL) anxiety in context and through which learners be able to select and implement anxiety reducing strategies that suits their specific conditions best.

\subsection{Research Questions}

This study aims at seeking answers to the following research questions:

RQ1: Does IST framework have any significant effect on decreasing the level of foreign language listening anxiety of EFL learners when implemented by a therapist?

RQ2: Does IST framework have a significant effect on decreasing the level of foreign language listening anxiety of EFL learners when implemented by the learners themselves?

\subsection{Research Hypotheses}

This paper is based on the following hypotheses.

1. IST framework will not reduce the level of FLLA of EFL learners when implemented by a therapist.

2. IST framework will not reduce the level of FLLA of EFL learners when implemented by the learners themselves.

\section{Review of the Literature}

\subsection{Foreign Language Listening Anxiety}

One of the first definitions for listening comprehension anxiety has been provided by Wheeless (1975) who has described it as "a receiver's apprehension, fear of misinterpretation, inadequately processing or not being able to adjust psychologically to messages sent by others" (p.263). In the literature, there are a number of studies that have concentrated on identifying the sources of listening comprehension anxiety among EFL learners. Kim (2000) has suggested that personal characteristics and text characteristics were the main sources of foreign language listening anxiety. However, Gonen (2009) believes that factors such as speed of speech, lack of clarity, characteristics of the listening text, and lack of visualization lead to listening comprehension anxiety.

Foreign language listening anxiety might have debilitating effects on students' performance, achievement, motivation, and learning experience. Therefore, having a comprehensive understanding of the negative effects of FLA is critical. Elkhafaifi (2005) has done a comprehensive study on the listening anxiety of learners of Arabic language and has found out that it has a negative effect on the learners' achievement. In a study conducted on MA students, MarzecStawiarska (2013) found two types of symptoms associated with listening comprehension anxiety: physical symptoms such as pounding heart and behavioral symptoms such as avoidance.

Some researchers considered the cognitive aspects of FLLA effects. For example, MacIntyre and Gardner (1994) held that FLA affects cognitive processing during input, processing, and output stages, explaining that "the combined effects of language anxiety at all three stages may be that, compared with relaxed students, anxious students have a smaller base of second language knowledge and have more difficulty demonstrating the knowledge that they do possess" (p. 301).

Given the negative effects of experiencing FLA, it seems essential to develop effective listening strategies to alleviate the anxiety of people in the context of second language learning and use. Recently, considerable scholarly attention has been paid to designing anxiety-reducing strategies. Three approaches have been proposed for reducing FLA, namely cognitive, affective, and behavioral approaches.

The cognitive approach focuses on changing learners' own cognitive appraisals (Hashemi \& Abbasi 2013; Hismanoglu \& Hismanoglu, 2010; Lee, 2016; Mejías, Applebaum, Applebaum, \& Trotter, 1991; Nagahashi, 2007). The affective approach attempts to eliminate or reduce the negativity of the foreign language experience (Cinkara, 2016; Ismail, 2016; Oxford, 2015; Ratanasiripong, Sverduk, Hayashino, \& Prince, 2010; Siagto-Wakat, 2016). In behavioral approach, premise is that FLA occurs as a result of poor language skills, and attempts to train learners in skills through different methods and techniques (Grant, Huang, \& Pasfield-Neofitou, 2014; Lord, 2005; Shams, 2005). 


\subsection{A Selective Review of Empirical Studies Related to Foreign Language Listening Anxiety and Strategies for Overcoming It}

There are a number of studies conducted on the relationship between foreign language listening anxiety and strategy use. With respect to using strategies to reduce listening anxiety, Gonen (2009) investigated the listening strategy use and the listening anxiety levels of sixty intermediate English learners. The results indicated that there is a negative relationship between listening strategy use and FL listening anxiety. Sánchez Solarte and Sánchez Solarte (2017) carried out a study at a Colombian university concerning the application of psychology-based strategies derived from the systemic therapy model to help FL learners face the anxiety symptoms they experience when exposed to oral performance in the second language. The purpose was to check if a brief group intervention in the classroom context would significantly reduce the anxiety levels associated with oral performance displayed by foreign language learners. The results suggest that the application of the strategies is highly effective and beneficial for the anxious L2 learners.

To conclude, even a cursory look at the literature reveals that although there is an abundance of research regarding foreign language anxiety, there is a dearth of research on providing a framework for FLA management in a systematic and individualized manner. Bearing this gap in mind, the researchers of the present study aimed at proposing a framework adopted from IST for reducing or ideally eliminating foreign language anxiety in a more contextualized way.

\subsection{Integrative Systemic Therapy}

Integrative Systemic Therapy (IST), formally known as Integrative Problem-Centered Meta-frameworks, is an integrative therapy (Pinsof et al., 2018). In IST, clinical decision-making is viewed as being most usefully grounded in the concepts and interventions strategies that have particular relevance to a particular case or problem and in how to collaborate in creating the most coherent, effective, and acceptable pathways to make changes for specific clients (Pinsof et al., 2018). IST provides both an integrative way of thinking about people and problems and also a specific path for intervention. It emphasizes creating a structure for case formulation and intervention that suggests under what situations which intervention strategies are likely to be most valuable (Pinsof et al., 2018). To solve a problem, IST uses a set of tools including a process named essence diagram.

According to Pinsof et al. (2018), "IST's essence diagram is a process through which a problem will be located and ideally solved" (p. 56). This diagram has a core set of processes including (a) defining the presenting problem, (b) constructing problem sequence, (c) identifying a solution sequence, and (d) implementing the solution sequence.

Since IST is problem-centered, the first step is to define the presenting problem. IST seeks a systematic understanding of the presenting problem, hence obtaining a problem definition is just the first step of beginning IST. The second component of essence diagram is to contextualize the problem by understanding how it is embedded within the client system - that is, how the system maintains the problem. A problem sequence is a predictable, patterned, and recursive set of actions, meanings, and emotions in which the problem is embedded. The problem sequence represents the client's first explanation of what is going on when the problem occurs. The third component of essence diagram is solution sequence. It can be defined as any change that contributes to solving the problem. IST fosters change through a systematic focus on changing sequences (Pinsof et al., 2018). Simply put, solution sequence replaces all or part of the problem sequence. The solution sequence can emerge from several sources: the knowledge of best practice about how to handle difficult situations, empirically supported findings from models of therapy that address particular problems or situations, therapist's experience, and common sense about how to solve problems.

\section{Methodology}

\subsection{Design of the Study}

This is a quasi-experimental research study which involves a pre-test, a treatment and a post-test, and then a comparison of results to assess the effects of the treatment. Quasi-experimental studies evaluate the association between an intervention and an outcome using experiments in which the intervention is not randomly assigned (Schweizer et al., 2016). Since the selection of the participants in this study was based on convenience non-random sampling, quasi-experimental design was considered an appropriate approach. To strengthen the design, a control group was included.

\subsection{Participants}


The participants of the study comprised 30 intermediate EFL students including 15 male and 15 female from a language institute in Tehran. The age of participants ranged from 23 to 27 at the time of the study. The participants were chosen based on convenience sampling.

\subsection{Instruments}

In this study, data were analyzed using Foreign Language Listening Anxiety Scale (Kim, 2000) and International English Language Testing System (IELTS) listening tests developed by the University of Cambridge. In order to measure the effects of the proposed model, the FLLAS was administered according to a pre-test and post-test design. This instrument, developed by Kim (2000), aims at measuring foreign language listening anxiety. The instrument has 33 items with a five-point Likert scale. The internal consistency estimate of reliability for the questionnaire was .93, and the test-retest reliability was .84 .

IELTS listening test was used to evaluate the listening performance of the students with the highest levels of foreign language listening anxiety. An IELTS listening test was administered before the treatments in order to obtain a baseline listening performance score on a band score of 0 to 9 and another IELTS listening test was administered after the treatments in order to examine possible improvement in listening performance in relation to the baseline scores.

\subsection{Data collection}

In order to select participants, copies of FLLAS questionnaire (Kim, 2000), which comprises 33 items with a fivepoint Likert scale, were distributed among the intermediate EFL students studying at a university in Tehran. Fifteen male and fifteen female students with the highest levels of listening anxiety were selected. They were randomly grouped into three groups of ten. Group A received therapy through therapeutic sessions under the supervision of an experienced therapist. Group B received instruction on how to use the model individually and in a self-treatment manner. There was a Group C, or the control group, which received no treatment.

After the selection procedure was done, the researchers of the study explained the aims and course of therapy to the participants in detail. Each student accepted participation in the study by signing an informed consent which made clear the purpose of the treatments, duration of the therapy, and the fact that they could quit the study at any given point in the process without any negative consequences. In order to obtain a baseline listening comprehension score, all 30 students were given a version of the 40-question IELTS, with scores out of 40 converted to band scores from 0 to 9 (pre-test) on the same day. Then, the numerical data was collected.

The course of the therapy was in accordance with IST's essence diagram - which is the proposed framework for FLA management in this study. The essence diagram represents a core set of processes that are repeated throughout the course of IST (Pinsof et al., 2018). These steps are as follows:

1. Convene a direct system and define the problem.

2. Locate the problem in the problem sequence.

3. Identify a solution sequence.

4. Implement the solution sequence.

5. Evaluate the outcome (successful or unsuccessful).

6. If successful, go to step 9, maintain the solution sequence and if unsuccessful identify the constraints preventing the solution sequence from working.

7. Use strategies to lift the constraints.

8. Implement the solution sequence.

9. Maintain the solution sequence.

10. Terminate therapy or repeat the steps with additional constraints and/or new problems.

In order to reach the aim of the first research question, the researchers cooperated with an experienced therapist in Kharazmi University in Tehran. All the required information including the aims and underpinning concepts were discussed with the therapist. In order to provide a full picture of the aims and IST's Essence diagram, the researchers 
translated some chapters of Integrative Systemic Therapy: Meta-frameworks for Problem Solving with Individuals, Couples, and Families by Pinsof et al. (2018) which is an all-inclusive book on IST.

Group A which included 5 male and 5 female students met individually with the therapist once a week for 4 weeks plus one follow-up session. The sessions were held in Persian which was the native language of the participants. Prior to the first session, the therapist examined the questionnaire completed by each participant. The first session mainly focused on knowing more about each participant, building a therapeutic alliance, and defining a problem sequence in which anxiety-triggering patterns were embedded. In this session, the therapist worked collaboratively with participants to get an initial picture of anxiety-triggering patterns. He sought a definition of the presenting problem which the participants too agreed on it.

In the second session, the therapist worked collaboratively with each student to suggest a solution sequence which replaced the problem sequence. In this session, the participants were encouraged to implement the solution sequence in the classroom context. The third session started with asking the participants how they experienced anxiety during class time while implementing the solution sequence. Afterward, the therapist looked for any constraints that possibly might interfere with the implementation of the solution sequence. Both the therapist and the participants worked collaboratively to revisit and improve strategies and interventions and lift the constraints. Then, the participants were encouraged to implement improved solution sequences in the classroom context. In the fourth session, the main focus was on receiving feedback from the participants about their experiences of anxiety during class time and reinforcement and stabilization of new patterns and solution sequences. Then, the participants were encouraged to implement the solution sequences for another week.

To seek an answer for the second research question, Group B (including 5 male and 5 female language learners) were given instruction on how to apply the model individually. A manual explaining the model, the procedure for identifying problem sequence and solution sequence, implementing the solution sequence, and finding possible constraints were given out to the students. Then, each student was asked to follow the model and identify their problem sequence, come up with a solution sequence, and implement the solution sequence in the classroom context. The students were recommended to use cognitive behavioral therapy (CBT) and other types of therapy to find anxietyreducing strategies that were best suited to their problem sequence. In the following session after the completion of the therapy courses, FLLAS was administered to all groups. In the next week, the IELTS listening test was administered in order to examine possible improvement in their listening comprehension in relation to the baseline scores.

\subsection{Data Analysis}

Using the Statistical Package for Social Sciences (SPSS) 23, the collected data were analyzed and the results were obtained. To this end, One Way ANOVA and Independent Samples Test were used. One Way ANOVA was implemented to determine whether there were any statistically significant differences between the three groups of control, therapist, and self-therapy in pre-test and post-test. Furthermore, Independent Samples Test was used to compare the means therapist and self-therapy groups to determine whether there was statistical evidence that the associated population means are significantly different.

\section{Results}

4.1 Does IST framework have any significant effect on decreasing the level of foreign language listening anxiety of individual EFL learner when implemented by a therapist?

\subsubsection{Results of the Questionnaires}

In order to find an answer to the first research question and check if the IST model can create any difference in the levels of anxiety among the foreign language learners, first a pre-test was run among all the three groups, i.e. control group, therapist group, and self-therapy group. Descriptive statistics for the three groups are presented in Table 1. 
Table 1. Descriptive statistics for comparison of the three groups- FLLA questionnaires

\begin{tabular}{|c|c|c|c|c|c|}
\hline Groups & $\mathrm{N}$ & Mean & Std. Deviation & Minimum & Maximum \\
\hline Control group & 10 & 100.6000 & 17.83380 & 63.00 & 123.00 \\
\hline $\begin{array}{l}\text { Therapist } \\
\text { group }\end{array}$ & 10 & 106.0000 & 12.56981 & 83.00 & 126.00 \\
\hline $\begin{array}{l}\text { Self-therapy } \\
\text { group }\end{array}$ & 10 & 108.9000 & 17.95952 & 76.00 & 131.00 \\
\hline Total & 30 & 105.1667 & 16.12683 & 63.00 & 131.00 \\
\hline
\end{tabular}

As indicated in Table 1, the mean scores of the three groups on FLLA questionnaires pretest were 100.6000, 106.0000, and108.9000 for the control group, the therapist group, and the self-therapy group, respectively. Then, the data were analyzed through One Way ANOVA and the results are reported in Tables 2.

Table 2. Multiple comparison between three groups in pre-test through One Way ANOVA- FLLA questionnaires

\begin{tabular}{|c|c|c|c|c|c|c|}
\hline \multicolumn{7}{|c|}{ Dependent Variable } \\
\hline \multicolumn{7}{|c|}{ Tukey HSD } \\
\hline \multirow{2}{*}{\multicolumn{2}{|c|}{ (I) groups }} & \multirow{2}{*}{$\begin{array}{c}\text { Mean } \\
\text { Difference (I-J) }\end{array}$} & \multirow{2}{*}{ Std. Error } & \multirow{2}{*}{ Sig. } & \multicolumn{2}{|c|}{$95 \%$ Confidence Interval } \\
\hline & & & & & Lower Bound & Upper Bound \\
\hline \multirow{2}{*}{$\begin{array}{l}\text { Control } \\
\text { group }\end{array}$} & therapist group & -5.4 & 7.29652 & 0.742 & -23.4911 & 12.6911 \\
\hline & $\begin{array}{l}\text { Self-therapy } \\
\text { group }\end{array}$ & -8.3 & 7.29652 & 0.5 & -26.3911 & 9.7911 \\
\hline \multirow{2}{*}{$\begin{array}{l}\text { Therapist } \\
\text { group }\end{array}$} & control group & 5.4 & 7.29652 & 0.742 & -12.6911 & 23.4911 \\
\hline & $\begin{array}{l}\text { self-therapy } \\
\text { group }\end{array}$ & -2.9 & 7.29652 & 0.917 & -20.9911 & 15.1911 \\
\hline \multirow{2}{*}{$\begin{array}{l}\text { Self-therapy } \\
\text { group }\end{array}$} & control group & 8.3 & 7.29652 & 0.5 & -9.7911 & 26.3911 \\
\hline & therapist group & 2.9 & 7.29652 & 0.917 & -15.1911 & 20.9911 \\
\hline
\end{tabular}

As the results indicate there is no significant difference between the three groups conduct in the pre-test: in all cases, the level of significance is higher than $0.05(0.742,0.500$, and 0.917$)$. The results of the ANOVA test confirm this conclusion as is shown in Table 3. 
Table 3. Results of ANOVA- FLLA questionnaires

\begin{tabular}{cccccc}
\hline & & & \multicolumn{3}{c}{ Pretest } \\
\hline & $\begin{array}{c}\text { Sum of } \\
\text { Squares }\end{array}$ & df & $\begin{array}{c}\text { Mean } \\
\text { Square }\end{array}$ & F & Sig. \\
\hline $\begin{array}{c}\text { Between } \\
\text { groups }\end{array}$ & 354.867 & 2 & 177.433 & 0.667 & 0.522 \\
$\begin{array}{c}\text { Within } \\
\text { groups }\end{array}$ & 7187.300 & 27 & 266.196 & & \\
Total & 7542.167 & 29 & & & \\
\hline
\end{tabular}

As Table 3 shows there is no significant difference between these groups in pre-test results (F ratio $=0.667$ and Sig. $=0.522$ ). After the treatment, FLLA questionnaires were once again distributed among students and the results are shown in the following tables.

Table 4. Results of descriptive statistics on the conduct of control group and therapist group in post-test- FLLA questionnaires

\begin{tabular}{|c|c|c|c|c|c|}
\hline \multicolumn{6}{|c|}{ Group Statistics } \\
\hline \multicolumn{2}{|c|}{ groups } & $\mathrm{N}$ & Mean & Std. Deviation & Std. Error Mean \\
\hline \multirow[t]{2}{*}{ Posttest } & control group & 10 & 104.1000 & 22.75693 & 7.19637 \\
\hline & $\begin{array}{l}\text { therapist } \\
\text { group }\end{array}$ & 10 & 94.6000 & 11.89024 & 3.76002 \\
\hline
\end{tabular}

As indicated in Table 4, the mean scores of the two groups on FLLA questionnaires post-test were different, 104.1000, 94.6000, for the control group and the therapist group, respectively. To check if there is a significant difference between the control group and the therapist group in post-test, an Independent Samples Test was conducted.

Table 5. Results of Independent Samples test- FLLA questionnaires

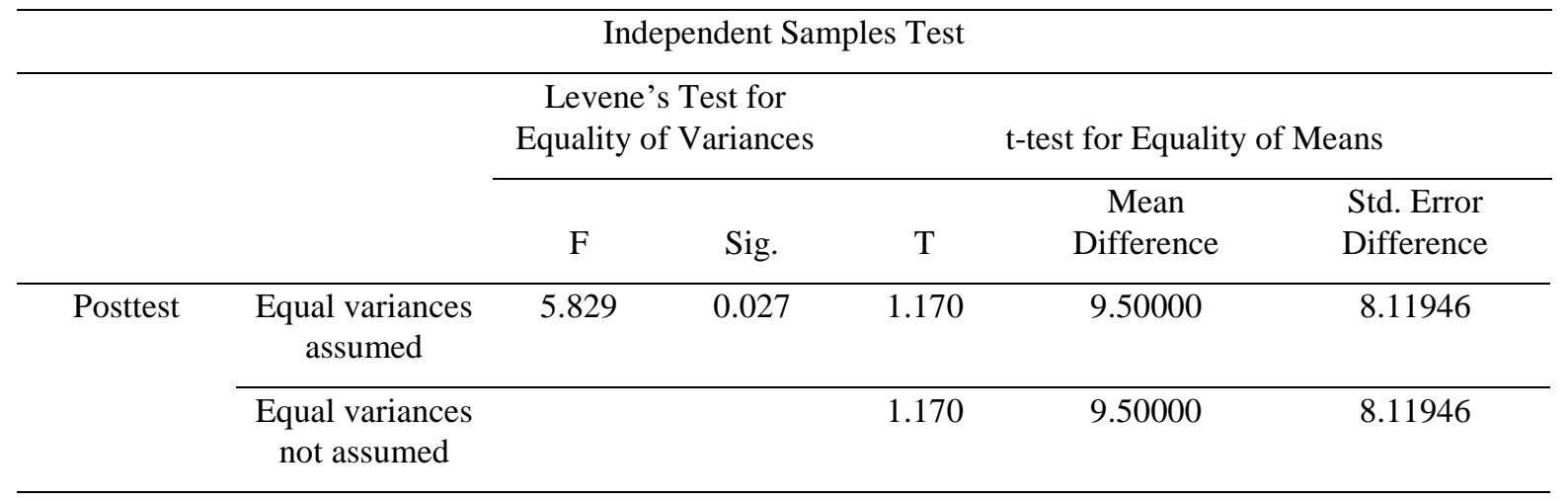

As the Independent Samples T-test indicates there is a significant difference between the control group and the therapist group in post-test. The level of significance equals .027 which is lower than .05 (sig. $=.027<.05)$. Regarding the first research question, analysis of the data revealed that the proposed framework created a significant difference 
in the levels of foreign language anxiety in the treatment group. This means that the use of the framework by a therapist can contribute to the reduction of FLA.

\subsubsection{Results of the IELTS listening tests}

With regard to the relation between listening anxiety and IELTS test performance, again a pre-test was run among all the three groups, i.e. control group, therapist group, and self-therapy group. The descriptive statistics are shown in Table 6 and the results of analysis of data through One Way ANOVA are reflected in Table 7.

Table 6. Descriptive statistics on the results of three groups' conduct in IELTS test (pretest)

\begin{tabular}{|c|c|c|c|c|c|}
\hline \multicolumn{6}{|c|}{ Descriptives } \\
\hline \multicolumn{6}{|c|}{ Pretest } \\
\hline & $\mathrm{N}$ & Mean & $\begin{array}{c}\text { Std. } \\
\text { Deviation }\end{array}$ & Minimum & Maximum \\
\hline Therapist group & 10 & 5.2500 & 1.49536 & 3.00 & 8.00 \\
\hline Self-therapy group & 10 & 5.2500 & 1.16070 & 3.50 & 7.00 \\
\hline Total & 30 & 5.4833 & 1.48256 & 3.00 & 8.00 \\
\hline
\end{tabular}

As shown in Table 6, the mean scores of the three groups on IELTS pretest were 5.9500, 5.2500, 5.2500 for the control group, the therapist group, and the self-therapy group, respectively. Then, the data were analyzed through One Way ANOVA and the results are reported in Tables 7.

Table 7. Multiple comparison between three groups in pre-test through One Way ANOVA

\begin{tabular}{|c|c|c|c|c|c|c|}
\hline \multicolumn{7}{|c|}{ Multiple Comparisons } \\
\hline \multicolumn{7}{|c|}{ Dependent Variable: } \\
\hline \multicolumn{7}{|c|}{ Tukey HSD } \\
\hline \multirow{2}{*}{\multicolumn{2}{|c|}{ (I) groups }} & \multirow[b]{2}{*}{$\begin{array}{l}\text { Mean Difference (I- } \\
\text { J) }\end{array}$} & \multirow[b]{2}{*}{$\begin{array}{l}\text { Std. } \\
\text { Error }\end{array}$} & \multirow[b]{2}{*}{ Sig. } & \multicolumn{2}{|c|}{$95 \%$ Confidence Interval } \\
\hline & & & & & $\begin{array}{l}\text { Lower } \\
\text { Bound }\end{array}$ & $\begin{array}{l}\text { Upper } \\
\text { Bound }\end{array}$ \\
\hline \multirow[t]{2}{*}{ Control group } & therapist group & 0.70000 & 0.66930 & 0.555 & -0.9595 & 2.3595 \\
\hline & $\begin{array}{l}\text { Self-therapy } \\
\text { group }\end{array}$ & 0.70000 & 0.66930 & 0.555 & -0.9595 & 2.3595 \\
\hline \multirow[t]{2}{*}{ Therapist group } & control group & -0.70000 & 0.66930 & 0.555 & -2.3595 & 0.9595 \\
\hline & $\begin{array}{l}\text { Self-therapy } \\
\text { group }\end{array}$ & 0.00000 & 0.66930 & 1.000 & -1.6595 & 1.6595 \\
\hline \multirow{2}{*}{$\begin{array}{l}\text { Self-therapy } \\
\text { group }\end{array}$} & control group & -0.70000 & 0.66930 & 0.555 & -2.3595 & 0.9595 \\
\hline & therapist group & 0.00000 & 0.66930 & 1.000 & -1.6595 & 1.6595 \\
\hline
\end{tabular}


As the results indicate there is no significant difference between the three groups conduct in pre-test: in all cases the level of significance is higher than $0.05(0.555,0.555$ and 1.000). The results of the ANOVA test confirm this conclusion as is shown in Table 8.

Table 8. Results of ANOVA

\begin{tabular}{ccccccc}
\hline \multicolumn{1}{c}{ ANOVA } & & & & \\
\hline & Pretest & & & & & \\
\hline & & Sum of & & Mean & & \\
Squares & df & Square & F & Sig. \\
\hline Between Groups & 3.267 & 2 & 1.633 & 0.729 & 0.492 \\
\hline Within Groups & & 60.475 & 27 & 2.240 & & \\
\hline Total & 63.742 & 29 & & & \\
\hline
\end{tabular}

As Table 8 shows there is no significant difference between these groups in pre-test results ( $F$ ratio $=0.729$ and Sig. $=0.492$ ). After the treatment, a post-test was conducted and the results are as follows.

Table 9. Descriptive statistics on the conduct of control and therapist group in post-test

\begin{tabular}{lccccc}
\hline & \multicolumn{5}{c}{ Group Statistics } \\
\hline groups & & N & Mean & $\begin{array}{c}\text { Std. } \\
\text { Deviation }\end{array}$ & Std. Error Mean \\
\hline Posttest & $\begin{array}{c}\text { control } \\
\text { group }\end{array}$ & 10 & 6.4000 & 1.34990 & 0.42687 \\
\cline { 2 - 5 } & $\begin{array}{c}\text { therapist } \\
\text { group }\end{array}$ & 10 & 5.6000 & 1.50555 & 0.47610 \\
\hline
\end{tabular}

As indicated in Table 9, the mean scores of the two groups on IELTS post-test were, 6.4000, 5.6000, for the control group and the therapist group, respectively. To check if there is a significant difference between the control group and the therapist group in post-test, an Independent Samples Test was conducted. 
Table 10. Results of Independent Samples Test

Independent Samples Test

\begin{tabular}{|c|c|c|c|c|c|c|c|}
\hline & & \multicolumn{2}{|c|}{$\begin{array}{c}\text { Levene's Test for } \\
\text { Equality of } \\
\text { Variances }\end{array}$} & \multicolumn{4}{|c|}{ t-test for Equality of Means } \\
\hline & & $\mathrm{F}$ & Sig. & $\mathrm{t}$ & df & $\begin{array}{c}\text { Mean } \\
\text { Difference }\end{array}$ & $\begin{array}{l}\text { Std. Error } \\
\text { Difference }\end{array}$ \\
\hline \multirow[t]{2}{*}{ Posttest } & $\begin{array}{c}\text { Equal } \\
\text { variances } \\
\text { assumed }\end{array}$ & 0.058 & 0.812 & 1.251 & 18 & 0.80000 & 0.63944 \\
\hline & $\begin{array}{c}\text { Equal } \\
\text { variances not } \\
\text { assumed }\end{array}$ & & & 1.251 & 17.790 & 0.80000 & 0.63944 \\
\hline
\end{tabular}

According to the Independent Samples T-test, there is not any significant difference between the control group and the therapist group in the post-test. The level of significance equals 0.812 which is higher than .05 (sig. $=.812>.05$ ). Therefore, we can conclude that the reduction of foreign language listening anxiety could not improve the students' performance on the IELTS listening test in the short run.

4.2 Does IST framework have a significant effect on decreasing the level of foreign language listening anxiety of EFL learners when implemented independently by the learners themselves?

\subsubsection{Results of the Questionnaires}

In order to probe the second research question regarding the effectiveness of the proposed framework in FLLA reduction when implemented by the EFL learners, Independent samples test was performed between the scores of questionnaires at post-test among control and self-therapy groups. The results are reported in the following tables.

Table 11. Results of descriptive statistics on control and self-therapy groups answers to the questionnaire

\begin{tabular}{|c|c|c|c|c|c|}
\hline \multicolumn{6}{|c|}{ Group Statistics } \\
\hline \multicolumn{2}{|c|}{ groups } & $\mathrm{N}$ & Mean & Std. Deviation & Std. Error Mean \\
\hline \multirow[t]{2}{*}{ Posttest } & control group & 10 & 104.1000 & 22.75693 & 7.19637 \\
\hline & $\begin{array}{c}\text { Self-therapy } \\
\text { group }\end{array}$ & 10 & 96.0000 & 12.97005 & 4.10149 \\
\hline
\end{tabular}

As shown in Table 11 above, the mean scores of the two groups on FLLA questionnaires post-test were different, 104.1000, 96.0000, for the control group and the self-therapy group, respectively. To check if there is a significant difference between the control group and the self-therapy group in post-test, an Independent Samples Test was conducted. 
Table 12. Results of Independent Samples Test

Independent Samples Test

\section{Levene's Test for}

Equality of

Variances

t-test for Equality of Means

\begin{tabular}{|c|c|c|c|c|c|c|c|}
\hline & & $\mathrm{F}$ & Sig. & $\mathrm{t}$ & df & $\begin{array}{c}\text { Mean } \\
\text { Difference }\end{array}$ & $\begin{array}{l}\text { Std. Error } \\
\text { Difference }\end{array}$ \\
\hline \multirow[t]{2}{*}{ Posttest } & $\begin{array}{c}\text { Equal } \\
\text { variances } \\
\text { assumed }\end{array}$ & 4.969 & 0.039 & 0.978 & 18 & 8.10000 & 8.28312 \\
\hline & $\begin{array}{c}\text { Equal } \\
\text { variances not } \\
\text { assumed }\end{array}$ & & & 0.978 & 14.289 & 8.10000 & 8.28312 \\
\hline
\end{tabular}

As the analysis indicates, the level of significance equals .039 , which is lower than .05 (sig. $=.039<.05)$. This means that there is a significant difference between the control group and the self-therapy group after the treatment. In other words, the proposed framework was quite effective in managing and ideally removing foreign language listening anxiety when implemented by EFL learners.

\subsubsection{Results of the IELTS Tests}

In order to compare the results of IELTS tests among control and self-therapy groups at post-test, Independent Samples Test was administered. Tables 13 and 14 summarize the results.

Table 13. Results of descriptive statistics on control and self-therapy groups' conduct in IELTS test

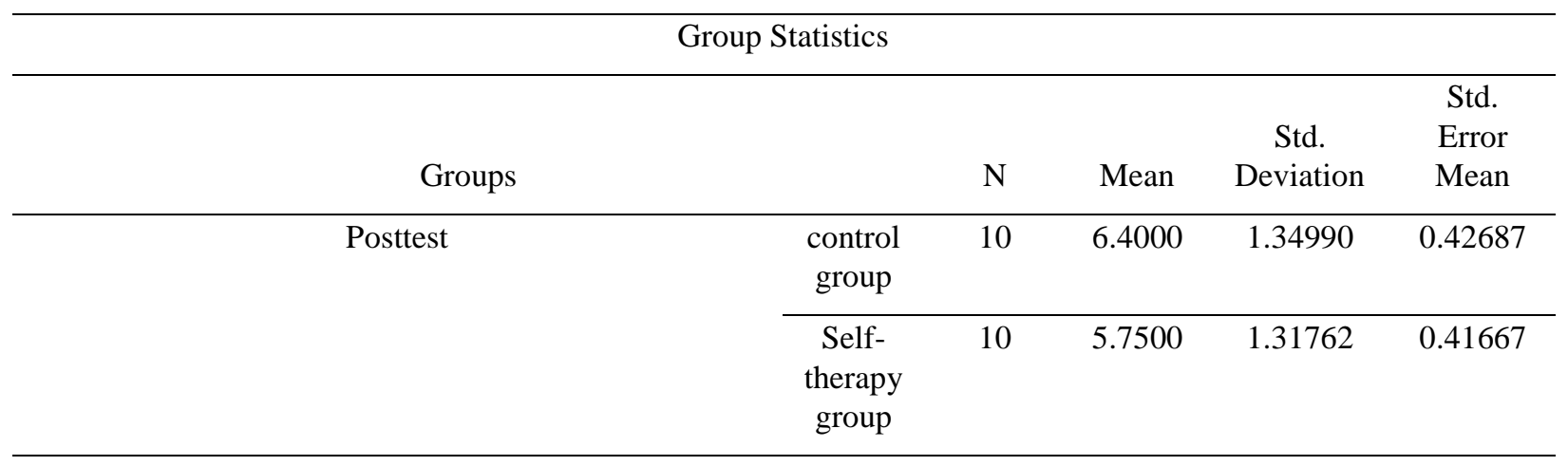

According to the analysis shown in Table 13, the mean scores of the two groups on IELTS post-test were, 6.4000, 5.7500 , for the control group and the self-therapy group, respectively. To check if there is a significant difference between the control group and the self-therapy group in post-test, an Independent Samples Test was conducted. The result is presented in Table 14. 
Table 14. Results of Independent Samples Test

Independent Samples Test

\begin{tabular}{|c|c|c|c|c|c|c|c|c|}
\hline & & \multicolumn{2}{|c|}{$\begin{array}{c}\text { Levene's Test for } \\
\text { Equality of } \\
\text { Variances }\end{array}$} & \multicolumn{5}{|c|}{ t-test for Equality of Means } \\
\hline & & $\mathrm{F}$ & Sig. & $\mathrm{t}$ & df & $\begin{array}{l}\text { Sig. (2- } \\
\text { tailed) }\end{array}$ & $\begin{array}{c}\text { Mean } \\
\text { Difference }\end{array}$ & $\begin{array}{l}\text { Std. Error } \\
\text { Difference }\end{array}$ \\
\hline \multirow[t]{2}{*}{ posttest } & $\begin{array}{c}\text { Equal } \\
\text { variances } \\
\text { assumed }\end{array}$ & 0.307 & 0.586 & 1.090 & 18 & 0.290 & 0.65000 & 0.59652 \\
\hline & $\begin{array}{c}\text { Equal } \\
\text { variances } \\
\text { not assumed }\end{array}$ & & & 1.090 & 17.989 & 0.290 & 0.65000 & 0.59652 \\
\hline
\end{tabular}

As seen in the above tables, the level of significance equals 0.586 which is higher than .05 (sig. $=.856>.05$ ). Hence, there is not any significant difference between the control group and the self-therapy group in the post-test. As was the case for the therapist group, foreign language listening anxiety reduction didn't lead to any significant improvement in the students' performance on the IELTS listening test.

\section{Discussion}

There have been numerous studies on the negative effects of listening anxiety on learning English language and performance of language learners (Aida, 1994; Hewitt \& Stephenson, 2011; Philips, 1992) and the researchers have suggested different ways for reducing this anxiety (Franco et al., 2010; Oxford, 2015; Ramsburg \& Youmans, 2014).

The first part of this study was an attempt to find out if a framework based on IST had any effect on reducing FLLA among Iranian English language learners or not. To this end, the Foreign Language Listening Anxiety Scale (FLLAS) questionnaire developed by Kim (2000) was used. The results of comparison and analysis of the answers of the control group, therapist group, and self-therapy group before and after the treatment indicated that there was a fairly significant decrease in the students' foreign language listening anxiety after the treatment was conducted. The data analysis through independent samples test showed the level of significance of difference equals .027 which means that the proposed framework adopted from IST therapy could relieve the students' foreign language listening anxiety when used by the therapist.

The finding of this study is in line with the findings of previous studies which followed other forms of therapy or strategies. As far as mere application of anxiety-reducing strategies is concerned, this finding agrees with those in Cinkara (2016), Hashemi and Abbasi (2013), and Shams (2005) who found that the use of strategies adopted from cognitive approach, affective approach, and behavioral approach significantly reduced the level of foreign language anxiety in language learners.

In particular, the finding of this study is in accordance with the finding obtained in Sánchez Solarte and Sánchez Solarte (2017) who found that the application of psychology-based strategies derived from the systemic therapy model is highly effective and beneficial for the anxious L2 learners. However, the level of significance of difference in the present paper is nearer to zero and this shows IST has been much more effective. The possible reason for this could be due to the systematic selection of strategies that was based on the specific condition and needs of each individual learner. Every strategy was selected with the help of the therapist based on the specific accounts of the learners about their problems. Hence, the strategies were directed at the roots of their anxiety. Therefore, it is recommended that therapists who are interested in the area of foreign language anxiety management use the framework proposed in this study.

With regard to the second research question, the effectiveness of the proposed framework when implemented by the learners was explored. Based on obtained results, there have been major improvements in the learners' levels of FLLA 
in the self-therapy group. Therefore, it can be suggested that the proposed framework was also effective even when used by the learners because the experiment probably increased the learners' understanding of foreign language anxiety and gave them a tool to address their anxiety in a more systematic customized manner. In this way, they were empowered to take steps to identify the main causes of their foreign language anxiety, select, and implement the proper strategies.

Foreign language anxiety can adversely affect language learning and achievement. "One of the most consistent findings in the second language acquisition (SLA) literature is that higher levels of language anxiety are associated with lower levels of language achievement" (MacIntyre \& Gregersen, 2012b, p. 103). For instance, the study conducted by Aida (1994) showed that the learners of Japanese with high levels of anxiety, as measured by the FLCAS, had significantly lower final grades in the course compared to the low anxiety group.

Therefore, in order to check if the reduction of FLLA can improve the overall performance of the treatment group on the IELTS listening test, a pre-test post-test design was conducted. The level of significance equals 0.812 , which shows no significant difference in the scores of the treatment group after the treatment. The analysis of the data obtained from the IELTS scores after the treatment revealed a level of significance equaling 0.586 . This level of significance shows that the reduction of FLLA in these learners did not have any positive influence on their listening performance in the IELTS test. This finding aligns with the results of a study conducted by In'nami (2006) that found listening-test anxiety and listening performance to be unrelated. He attributed poor performance in listening tests to other factors, such as test-takers' English listening proficiency and confidence in their use of strategies to control anxiety.

There could be possible reasons for the obtained results in this study. In fact, the way IELTS scores were calculated could be a factor. The IELTS listening scores were calculated by the number of correct answers each respondent had out of the 40 questions in the test. Then, the numbers were related to band scores from 1 to 9 . For instance, a respondent who had 22 correct answers got 4 on the test. However, he must have had total correct answers of 26 to 29 in order to get a 4.5 or 5 on the test. But, the subject got 25 on the test. Therefore, he had the same score as 4 . The improvement from 22 to 25 was not accounted for by the IELTS band score. Another point is that for improvements in any skill 4 weeks of practice is not really enough and if it was possible to continue this experiment for at least 3 months we could then judge the learners' progress in performing the tests more definitely and rationally.

\section{Conclusion}

\subsection{Summary of the Main Findings and Concluding Remarks}

This study was conducted to propose a framework adopted from IST through which EFL learners can select foreign language listening anxiety reducing strategies which has most relevance to their conditions. A therapist followed the model and worked with a treatment group. In addition, attempts were made to find out whether the model can be used by EFL learners by themselves effectively or not. To this aim, 30 EFL learners were chosen. The participants of the present study were at the intermediate level of proficiency and divided into groups of 10.

Results of the first phase of the data analysis uncovered a significant reduction in foreign language listening anxiety scores after the treatment. however, there was not a significant positive relationship between the pre-test and post-test scores of IELTS listening test of the EFL learners and their numbers on FLLA questionnaires. In fact, the model was effective in reducing foreign language listening anxiety of the EFL learners when it was implemented by the therapist. Moreover, the results of the data analysis for the second research question regarding the effectiveness of the model when it was followed and used by the EFL learners on their own revealed that there was a reduction in foreign language listening anxiety scores reduction in foreign language listening anxiety scores. Furthermore, the results revealed that there was not a positive relationship between a lower foreign language listening anxiety level and a higher score on IELTS listening exam.

\subsection{Pedagogical Implications}

Based on the results reported above, some pedagogical implications can be made as the following:

1. Based on the current study, the first implication we can make is the fact that foreign language anxiety in general and foreign language listening anxiety in particular should be identified and examined in context. The results show that FLLA can be best dealt with through personalization of the selection procedure of FLA reducing strategies. 
2. This study has demonstrated that effective use of the proposed framework by therapists is significantly associated with the reduction of foreign language listening anxiety in language learners. Hence, the proposed framework can assist therapists in selecting FLA reducing strategies which have the most relevance to the EFL learners.

3. The next pedagogical implication concerns the management of FLA by the EFL learners themselves. The results suggested that the proposed framework is quite effective when implemented by the EFL learners themselves.

Therefore, the proposed framework can empower EFL learners with FLLA to independently cope with their anxiety in a systematic manner.

\subsection{Suggestions for Further Research}

This study was conducted investigating the effectiveness of a framework adopted from IST in addressing foreign language listening anxiety among intermediate EFL learners. Other similar researches are suggested to be done to investigate the efficiency of the framework in dealing with other types of foreign language anxiety, namely speaking, reading, and writing foreign language anxieties. Secondly, intermediate EFL learners were only included in the present study. Hence, future studies should include learners with elementary and advanced levels of language proficiency. Thirdly, there was a limited sample included in this study. If there were more students, the generalizability of the obtained results could be improved. Therefore, other studies could be done with a larger sample. Fourthly, in the present study time of intervention was limited. The course of the treatment involved four sessions in a month. Other studies can be done with a longer period of treatment so as to obtain more accurate results.

\section{References}

Aida, Y. (1994). Examination of Horwitz, Horwitz, and Cope's construct of foreign language anxiety: The case of students of Japanese. Modern LanguageJournal, 78(2), 155-168. https://doi.org/10.1111/j.15404781.1994.tb02026.x

Argaman, O., \& Abu-Rabia, S. (2002). The influence of language anxiety on English reading and writing tasks among native Hebrew speakers. Language, Culture and Curriculum, 15(2), 143-160. https://doi.org/10.1080/07908310208666640

Cheng, Y. (2002). Factors associated with foreign language writing anxiety. Foreign Language Annals, 35(6), 647656. https://doi.org/10.1111/j.1944-9720.2002.tb01903.x

Cinkara, E. (2016). Reflective practice and foreign language classroom anxiety: video-stimulated recall at work. Reflective Practice, 17(6), 694-707. https://doi.org/10.1080/14623943.2016.1206880

Dörney, Z. (2005). The psychology of the language learner: Individual differences in second language acquisition.

Mahwah, NJ: Lawrence Erlbaum.

Ehrman, M. E. (2002). Understanding the learner at the superior-distinguished threshold. In B. L. Leaver \& B. Shekhtman (Eds.), Developing professional-level language proficiency (pp. 245-259). Cambridge: Cambridge University Press.

Elkhafaifi, H. (2005). Listening comprehension and anxiety in the Arabic language classroom. The Modern Language Journal, 89(2), 206-220. https://doi.org/10.1111/j.1540-4781.2005.00275.x

Franco, C., Mañas, I., Cangas, A. J., \& Gallego, J. (2010). The applications of mindfulness with students of secondary school: Results on the academic performance, self-concept and anxiety. Knowledge Management, Information Systems, E-Learning, and Sustainability Research, Communications in Computer and Information Science, 111, 83-97. https://doi.org/10.1007/978-3-642-16318-0_10

Gardner, R. C. (1985). Social psychology and second language learning. London: Edward Arnold.

Gonen, M. (2009). The relationship between FL listening anxiety and FL listening strategies: The case of Turkish EFL learners. Proceedings of the 5th WSEAS/ IASME International conference on educational technologies (pp. 44-49). 
Grant, S., Huang, H., \& Pasfield-Neofitou, S. (2014). The authenticity-anxiety paradox: The quest for authentic second language communication and reduced foreign language anxiety in virtual environments. ProceediaTechnology, 13, 23-32. https://doi.org/10.1016/j.protcy.2014.02.005

Hashemi M., \& Abbasi, M. (2013). The role of the teacher in alleviating anxiety in language classes. International Journal of Applied and Basic Sciences, 4, 640-646.

Hewitt, E., \& Stephenson, J. (2011). Foreign language anxiety and oral exam performance: A replication of Phillips's MLJ study. Modern Language Journal, 96(2), 170-189. https://doi.org/10.1111/j.1540-4781.2011.01174.x

Hismanoglu, M., \& Hismanoglu, S. (2010). Teachers' preferences of pronunciation teaching techniques: traditional or modern? Procedia - Social and Behavioral Sciences, 2, 983-989. https://doi.org/10.1016/j.sbspro.2010.03.138

Horwitz, E. K. (2001). Language anxiety and achievement. Annual Review of Applied Linguistics, 21, 112-126. doi:10.1017/S0267190501000071

Horwitz, E. K., Horwitz, M. B., \& Cope, J. A. (1986). Foreign language classroom anxiety. The Modern Language Journal, 70(2), 125-132. https://doi.org/10.2307/327317

In'nami, Y. (2006). The effects of test anxiety on listening test performance. System, 34(3), 317-340. https://doi.org/10.1016/j.system.2006.04.005

Ismail, N. M. (2016). The effectiveness of an engaging program to reduce Saudi female university EFL students' foreign language anxiety and to enhance their motivation to learn English at Taif University. International Journal of Psychological Studies, 8(1), 92-105. https://doi.org/10.5539/ijps.v8n1p92

Kim, J. (2000). Foreign language listening anxiety: A study of Korean students learning English. Unpublished doctoral dissertation. Austin: The University of Texas.

Kleinmann, H. (1977). Avoidance behavior in adult second language acquisition. Language Learning, 27(1), 93-107. https://doi.org/10.1111/j.1467-1770.1977.tb00294.x

Krashen, S. D. (1982). Principles and practice in second language acquisition. University of Southern California: Pergamon Press Inc.

Lee, E. J. (2016). Reducing international graduate students' language anxiety through oral pronunciation corrections. System, 56, 78-95. http://dx.doi.org/10.1016/j.system.2015.11.006

Leaver, B. L., \& Atwell, S. (2002). Preliminary qualitative findings from a study of the processes leading to the Advanced Professional Proficiency Level (ILR 4). In In Leaver, B. L. and B. Shekhtman (Eds.), Developing professional-level language proficiency (pp.260-279). New York: Cambridge University Press.

Lord, G. (2005). Can we teach foreign language pronunciation? On the effects of a Spanish phonetics course. Hispania, 88(3), 557-567. https://doi.org/10.2307/20063159

MacIntyre, P. D., \& Gardner, R. C. (1994). The subtle effects of language anxiety on cognitive processing in the second language. Language Learning, 44(2), 283-305. https://doi.org/10.1111/j.1467-1770.1994.tb01103.x

MacIntyre, P., \& Gregersen, T. (2012b). Affect: The role of language anxiety and other emotions in language learning. In S. Mercer, S. Ryan, \& M. Williams (Eds.), Psychology for language learning (pp. 103-118). London: Palgrave Macmillan. https://doi.org/10.1057/9781137032829_8

Marzec-Stawiarska, M. (2013). Foreign language reading anxiety among advanced students of English - A pilot study. Acta Neophilologica, XV(1), 89-102.

Mejías, H., Applebaum, R. L., Applebaum, S. J., \& Trotter, R. T. (1991). Oral communication apprehension and Hispanics: An exploration of oral communication apprehension among Mexican American students in Texas. In E. K. Horwitz, \& D. J. Young (Eds.), Language anxiety: From theory and research to classroom implications (pp. 87-97). Englewood Cliffs, NJ: Prentice Hall.

Nagahashi, T. L. (2007). Techniques for reducing foreign language anxiety: Results of a successful intervention study. Akita City: Akita University Press. 
Oxford, R. L. (2015). How language learners can improve their emotional functioning: Important psychological and psychospiritual theories. Applied Language Learning, 25, 1-15.

Phillips, E. (1992). The effects of language anxiety on students' oral test performance and attitudes. Modern Language Journal, 76(1), 14-26. https://doi.org/10.2307/329894

Pinsof, W. M., Breunlin, D. C., Russell, W. P., Lebow, J. L., Rampage, C., \& Chambers, A. L. (2018). Integrative systemic therapy: Metaframeworks for problem solving with individuals, couples, and families. Washington, DC: American Psychological Association.

Ramsburg, J. R., \& Youmans, R. J. (2014). Meditation in the higher-education classroom: Meditation training improves student knowledge retention during lectures. Mindfulness, 5(4), 431-441. https://doi.org/10.1007/S12671-013-0199-5

Ratanasiripong, P., Sverduk, K., Hayashino, D., \& Prince, J. (2010). Setting up the next generation biofeedback program for stress and anxiety management for college students: A simple and cost effective approach. College Student Journal, 44, 97-100.

Saito, Y., Horwitz, E. K., \& Garza, T. J. (1999). Foreign language reading anxiety. The Modern Language Journal, 83(2), 202-218. https://doi.org/10.1111/0026-7902.00016

Sánchez Solarte, A. C., \& Sánchez Solarte, A. (2017). From therapy to instruction: The effect of systemic strategies on the oral performance of foreign language learners. HOW, 24(2), 160-178. http://dx.doi.org/10.19183/how.24.2.393

Schweizer, M., Braun, B., \& Milstone, A. (2016). Research methods in healthcare epidemiology and antimicrobial stewardship - quasi-experimental designs. Infection Control \& Hospital Epidemiology, 37(10), 1135-1140. doi:10.1017/ice.2016.117

Scovel, T. (1978). The effect of affect: A review of anxiety literature. Language Learning, 28(1), 129-142. https://doi.org/10.1111/j.1467-1770.1978.tb00309.x

Shams, A. N. (2005). The use of computerized pronunciation practice in the reduction of foreign language classroom anxiety. Doctoral dissertation. Tallahassee: Florida State University.

Siagto-Wakat, G. (2017). Doodling the nerves: surfacing language anxiety experiences in an English language classroom. RELC Journal, 48(2), 226-240. https://doi.org/10.1177/0033688216649085

Vandergrift, L. (1999). Facilitating second language listening comprehension: acquiring successful strategies. ELT Journal, 53(3), 168-176. http://dx.doi.org/10.1093/elt/53.3.168

Walqui, A. (2000). Contextual factors in second language acquisition. ERIC Digest. ERIC Clearinghouse on Languages and Linguistics, Document ED444381, Washington, DC.

Wheeless, L. R. (1975). An investigation of receiver apprehension and social context dimensions of communication apprehension. The Speech Teacher, 24(3), 261-268. https://doi.org/10.1080/03634527509378169

Woodrow, L. (2006). Anxiety and speaking English as a second language. RELC Journal, 37(3), 308-328. http://dx.doi.org/10.1177/0033688206071315

Young, D. J. (1991). Language anxiety from the foreign language specialist's perspective: Interviews with Krashen, Omaggio Hadley, Terrell and Rardin. Paper presented at the Annual Meeting of the Central States Conference on the Teaching of Foreign Languages (Indianapolis, IN, March 21-24, 1991).

Zhai, L. (2015). Influence of anxiety on English listening comprehension: An investigation based on the freshmen of English majors. Studies in Literature and Language, 11(6), 40-47. http://dx.doi.org/10.3968/7952 